\title{
What's in a name: Dimensions of social learning in teacher groups
}

Citation for published version (APA):

Vrieling, E., Van den Beemt, A., \& De Laat, M. (2016). What's in a name: Dimensions of social learning in teacher groups. Teachers and Teaching: Theory and Practice, 22(3), 273-292.

https://doi.org/10.1080/13540602.2015.1058588

DOI:

10.1080/13540602.2015.1058588

Document status and date:

Published: 01/01/2016

Document Version:

Peer reviewed version

Document license:

CC BY-NC-ND

Please check the document version of this publication:

- A submitted manuscript is the version of the article upon submission and before peer-review. There can be important differences between the submitted version and the official published version of record. People interested in the research are advised to contact the author for the final version of the publication, or visit the DOI to the publisher's website.

- The final author version and the galley proof are versions of the publication after peer review.

- The final published version features the final layout of the paper including the volume, issue and page numbers.

Link to publication

\section{General rights}

Copyright and moral rights for the publications made accessible in the public portal are retained by the authors and/or other copyright owners and it is a condition of accessing publications that users recognise and abide by the legal requirements associated with these rights.

- Users may download and print one copy of any publication from the public portal for the purpose of private study or research.

- You may not further distribute the material or use it for any profit-making activity or commercial gain

- You may freely distribute the URL identifying the publication in the public portal.

If the publication is distributed under the terms of Article 25fa of the Dutch Copyright Act, indicated by the "Taverne" license above, please follow below link for the End User Agreement:

https://www.ou.nl/taverne-agreement

Take down policy

If you believe that this document breaches copyright please contact us at:

pure-support@ou.nl

providing details and we will investigate your claim.

Downloaded from https://research.ou.nl/ on date: 26 Apr. 2023 


\section{What's in a Name: Dimensions of Social Learning in Teacher Groups}

E. Vrieling*, A. van den Beemt, M. de Laat

Welten Institute, Open University, Heerlen, the Netherlands

*Corresponding author. PO Box 2960, 6401 DL, Heerlen, the Netherlands. E-Mail:

emmy.vrieling@ou.nl

Accepted paper to be published in may 2015 in 'Teachers and Teaching: Theory and Practice'. 


\section{What's in a Name: Dimensions of Social Learning in Teacher Groups}

Induced by a literature review, this paper presents a framework of dimensions and indicators highlighting the underpinning aspects and values of social learning within teacher groups. Notions of social networks, communities of practice and learning teams were taken as the main perspectives to influence this social learning framework. The review exercise resulted in four dimensions: (1) practice, (2) domain and value creation, (3) collective identity and (4) organization. The indicators corresponding to these dimensions serve as the foundation for understanding social learning in practice. The framework of dimensions and indicators can be of assistance for researchers as well as teacher groups that aim to assess their views on social learning and analyse whether these views fit the learning goals of the group, or that adjustments are required. In this way, learning processes within groups of teachers can be improved.

Keywords: social learning; collaborative learning; teacher groups; professional development 


\section{Introduction}

\subsection{Social learning in teacher groups}

During the last few decades, social learning activities of teacher groups have received a lot of attention within educational policy, practice and research. Social learning in teacher groups can be defined as: 'undertaking (a series of) learning activities by teachers in collaboration with colleagues, resulting in a change in cognition and/or behaviour at the individual and/or group level' (Doppenberg, Bakx, \& Den Brok, 2012, p. 548-549). This definition relates to social learning as sharing problems and insights in a constructive way, connecting with familiar concepts and using new knowledge that is collaboratively constructed through dialogues and social interactions (Wenger, Trayner, \& De Laat, 2011).

Increasingly, articles in teacher education journals use words such as 'teacher teams' (Knapp, 2010), 'teacher communities' (Little, 2003), or 'teacher networks' (Lieberman, 2000) to refer to social activities among teachers. All these types of social activities are found to stimulate and facilitate teachers' professional development in educational settings, despite their analytical differences (Lieberman \& Wood, 2003). Rather than focusing on theoretical differences and diversity in descriptions of social learning ('What's in a name'), the present study searches for all-embracing commonalities ('dimensions') and associated characteristics ('indicators') of social learning in teacher groups.

The goal of this search for common dimensions and indicators of social learning is to provide a theoretical framework that describes and characterizes social learning processes within teacher groups. Through synthesizing existing theories, related concepts and empirical research in the domain of social learning in teacher groups, a theoretical framework is developed to incorporate dimensions of social learning that play a role in the professional development of teachers.

To support the professional development of teachers in social groups, the focus of the present study is on social learning in groups of teachers, rather than on social learning in general. Traditionally, most teachers carry out their work individually, in their own classroom settings (Doppenberg et al., 2012). This isolated position can harm their continuous learning and development (Lieberman \& Pointer-Mace, 2010). In response to this situation, teachers can join forces to create teacher groups. The purpose of these groups is to increase teachers' learning opportunities, because social learning enhances learning beyond the classroom walls (Vrieling, Bastiaens, \& Stijnen, 2010). Through engaging in social groups, teachers hope to gain specific and concrete ideas that are directly related to their own classroom practice (Guskey, 2002; Van den Beemt, Ketelaar, Diepstraten, \& De Laat, 2014). The importance of 
this social learning approach is to acknowledge the unique settings, dynamics and desires of teacher groups, situated in practice.

As a starting point to elaborate on social learning in teacher groups, we discuss theoretical notions concerning three overarching configurations of social learning: (1) community learning, (2) network learning, and (3) team learning. These three perspectives serve as input for the literature review that informs our framework. With a focus on teachers the present study is, to our knowledge, the first effort to create a framework of dimensions and indicators related to a practice-driven perspective of social learning in both offline and online environments.

\subsection{Configurations of social learning}

In defining social learning, Wenger et al. (2011) theoretically distinguish between 'community' and 'network'. Members of a community are informally bound by what they do together and by what they have learned through their mutual engagement in these activities (Wenger, 1998). A community is about something: the learning partnership creates an identity around a common agenda or area for learning. In this way, shared learning and interest of the members keep the community together.

The term 'network' refers to a set of connections among people (Wenger et al., 2011). Social networks can be defined as 'the configurations of connectivity that exists when people interact with each other by communicating, sharing resources, and working, learning or playing together, supported through face-to-face interaction as well as through the use of educational, and information and communication technology' (Haythornthwaite \& De Laat, 2012, p. 352). A networked learning perspective focuses on the diversity of social relationships between people. From this perspective, the nature and strength of relationships and the impact of these relationships on learning is under attention (Hanraets, Hulsebosch, \& De Laat, 2011). Such networks can optimize the connectivity among teachers by using information technology.

Besides informal social groups, such as communities and networks, literature also distinguishes formal 'teams'. Teams can be defined as 'groups of people that work together cohesively toward a common goal' (Dechant, Marsick, \& Kasl, 1993, p.1). Team members 'have been assigned specific roles or functions to perform' (Salas, Dickinson, Converse, \& Tannenbaum, 1992). Where a community's life cycle is determined by tacit knowledge sharing in informal groups based on self-organization and volunteered participation with boundaries beyond the organization, team learning is defined by tasks rather than by 
knowledge. Furthermore, team learning is guided by an institutional schedule in formally instigated groups within organizations (Knapp, 2010).

\subsection{Dynamics in social configurations}

Although the three configurations of social learning all represent different foci (i.e., network learning on development of connections, community learning on identity development, team learning on formal learning structures) their definitions show considerable overlap. For example, the development of an identity is said to be typical of communities, but networks also develop identities (for instance in political networks). Likewise, the configurations of connectivity, said to be typical of networks, can be also found in communities, especially when members have specific roles (which overlaps with the definition of teams).

Furthermore, despite the theoretical distinction in 'pure' networks, communities and teams, practice often demonstrates mixed phenomena of social learning in groups of learners (Doornbos \& De Laat, 2012). Therefore, the focus of the present review study is narrowed down to aspects of social learning that are found to influence a group's ability to put theory into practice. Hence, this paper offers a reflection on 'What's in a name of social learning'? Groups of learners are dynamic, and their structure changes depending on the needs of the participants. In some occasions, the group shows more aspects of a community, while in other activities, the term network is more suitable.

By concentrating on the question whether a group is a community, a team or a network, the important question that lies behind it might be forgotten. It is the question about how the social configuration time and again facilitates the group's ambition to develop and maximise knowledge creation and sharing during social learning activities. The discourse on social learning reflects the importance of creation and sharing. Central concepts in this context are for instance mutually shared cognition (Van den Bossche, Gijselaers, Segers, \& Kirschner, 2006), perceived group efficiency (Strijbos, Martens, Jochems, \& Broers, 2004) or quality of team meetings (Doppenberg et al., 2012). Other studies focus on learning behaviour, defined as an on-going process of collective reflection and action characterized by exploring, reflecting, discussing errors and unexpected outcomes, seeking feedback, and experimentation (Savelsbergh, Van der Heijden, \& Poell, 2009). Furthermore, the importance of social aspects of group learning is also reflected in studies scrutinizing methodological issues related to this subject (Goodman \& Dabbish, 2011).

The complexity of social learning does not allow for strict typology of such groups in terms of 'pure' community-, network- or team-learning. Therefore, in line with Wenger et al. 
(2011), the present study views characteristics of communities, networks and teams as integral aspects of learning groups. In this way, the group can be assessed based on its social configuration, resulting in an adequate advice aimed at professional growth of its members.

\section{Methodology}

In an effort to develop a framework for social learning in teacher groups, a literature review was performed. The review focused on finding conceptual and empirical studies discussing the underpinning values and aspects of social learning configurations concerning group learning by teachers. The studies presented in this review were identified in several steps. First, searches on the database of EBSCOhost were applied. This meta-database includes, amongst others, the ERIC and Web of Science databases. Peer-reviewed journal articles and book chapters published between January 1st 2000 and September 20th 2013 were included. Only journals registered by the Social Science Citation Index (SSCI) or by the Dutch Interuniversity Centre for Educational Research (ICO) and peer-reviewed international books were selected, because these are considered proper academic sources for the present article. The following keywords were used for a Boolean search: 'team learning' OR 'community learning' OR 'network learning' AND 'teacher'. This search resulted in 79 articles.

The aim of the literature research was to recognize dimensions and core features of social learning configurations. For this purpose, the abstract, summary and references of all selected sources were studied first, resulting in a final selection of articles. After reading the articles, 58 were left out of the analysis because they did not discuss social learning of teachers. Third, the so-called snowball method of checking references in the remaining articles was applied. This resulted in two extra references relevant to our aim. In total 23 studies (Appendix 1) were read in depth and provided the basis for further analysis.

Because we aimed at finding categories of social learning (that we labelled as dimensions) and their specific features (that we labelled as indicators), all findings published in the articles were analysed on their specific dimensions (Appendix 1, column 6) and indicators (Appendix 1, column 7). This analysis resulted in a preliminary sketch of four superordinate Meta dimensions of social learning. In our view, these dimensions referred to group activities, what a group is about, the nature of a group, and how it functions. However, in order to do justice to nuances presented in the reviewed literature, the labels of the four Meta dimensions were adjusted to: practice (professional activities that the group is focused on; deduced from the dimensions 'embeddedness in practice' and 'integrating knowledge sharing and work'), domain and value creation (the knowledge area and purpose of the group 
combined with its performance; deduced from the dimensions 'shared domain', 'knowledge sharing', meaningful activity' and 'social capital'), collective identity (its sense of being a coherent group; deduced from the dimensions 'group identity', 'shared vision', 'shared ownership' and 'shared identity'), and organization (how the group structures its social space; deduced from the dimensions 'shared interactional repertoire' and 'self organization'). These adjustments also serve our purpose to develop a future instrument for assessing and improving social learning among teachers (see also Discussion Section).

The first Meta dimension concerns the problems or challenges participants are confronted with in practice (De Laat, 2012b). The second, third and fourth Meta dimensions of teacher groups are also distinguished in the work of Wenger (1998): shared domain (a joint enterprise as understood and continually negotiated by its members); group identity (mutual engagement that binds teachers together in a social entity), and shared interactional repertoire (shared practice of and beliefs on how teachers in a group interact).

During the content analysis, the properties of the textual information were systematically identified by their relationship with the dimensions and their indicators. Subsequently we checked whether the dimensions and indicators matched our findings as operationalized in the concepts of the Meta dimensions (Appendix 1, column 8) and Meta indicators (Appendix 1, column 9). This overview provided input for a description of the final four dimensions and 11 representative indicators in the 'Findings' section of the present article.

Besides the dimensions and indicators of social learning, Appendix 1 also categorizes the selected sources by name of first author and year of publication (column 1), type of learning (community learning, network learning, team learning; column 2), main research approach (conceptual, empirical; column 3), data collection (column 4) and main findings (column 5).

\section{Findings}

The literature included in our review focuses on teams, communities or networks as theoretical orientations informing group learning of teachers. Rather than synthesizing labels from existing literature, most studies in our review tend to present new labels for dimensions and indicators related to social learning of teachers. One could wonder what's in a name, because notwithstanding this analytical distinction and the wide range of labels, in essence most dimensions can be traced back to the four dimensions that guided our quest. 
In what follows we discuss each of the four dimensions and their subsequent indicators, based on the results from the literature review. The studied manuscripts consist of 15 empirical and 8 conceptual sources indicating that the findings have a robust backing on conceptual as well as empirical data. The discussion is followed by a brief summary of the findings culminating into 11 questions that reflect on, for instance, how group members act, how they talk about aspirations, or how a shared identity develops, thus helping to describe the current social configuration of the learning group.

\subsection{Dimension 1: Practice}

For many teachers, it is important that the knowledge created and shared in the group relates to their day-to-day activities (Agterberg, Van den Hooff, Huysman, \& Soekijad, 2009). The relationship with everyday practice refers to the extent to which group knowledge is embedded and relevant to the participants' local practices. In such practices professionals encounter challenges that require a learning process in order to solve them. This learning is more than just experiential learning, involving everyday problem solving. Teacher groups can reflect upon urgent personal or organisational problems. However, they can also develop into more stable and sustained collective learning groups that integrate social learning in their practice (De Laat \& Coenders, 2011).

In a society that requires lifelong learning, the ability to steer one's own learning is becoming increasingly important to be successful in academic as well as in non-academic contexts (Vrieling et al., 2010). When teacher groups are pro-actively discussing work related topics to broaden or deepen their knowledge and skills in cooperation with people who share the same questions or challenges, temporarily learning activities can develop towards a more permanent social learning attitude (De Laat, 2012a).

Based on the review results the dimension Practice can be summarised in two indicators:

- 'Integrated or non-integrated activities', representing the extent to which group knowledge and activities are integrated in everyday practice;

- 'Temporarily or permanent activities', which describes the social learning attitude as reflected in the duration or sustainability of learning activities.

\subsection{Dimension 2: Domain and Value Creation}

Knowledge sharing in groups is referred to as the sharing of experience and expertise among group members (Agterberg et al., 2009). Group learning resulting from these activities is 
always topical, for example a particular interest or (knowledge) domain that brings people together (Wenger, 1998). This shared interest or domain is the basis for a 'deep level similarity' among group members (Emmerik, Jawahar, Schreurs, \& De Cuyper, 2011), despite their diversity in voices or language (Barak, Gidron, \& Turniansky, 2010). By listening to perspectives of others in dialogues, new views can be examined to alter old views. These dialogues, often enforced by questions of novices (Barak et al., 2010; Leh, Kouba, \& Davis, 2005) can lead to reframing: a process of transforming existing perceptions into a new understanding or frame, possibly resulting in the broadening or deepening of knowledge and practice. In this way, the group integrates these views into a new mental construct that is collectively held.

Participating group members can strive for individual or common goals. When group members become more aligned, their goals develop and reflect the collective goals (Meirink, Imants, Meijer, \& Verloop, 2010). In this way, the capacity of the group to create shared value is developed (Wenger, 1998) and all members become interested in results of the group. If groups aim at the development of shared goals, it is suggested to ensure group ownership rather than individual ownership of the direction of group activities (Akkerman, Petter, \& De Laat, 2008). When no shared agenda is defined, a lack of mutual trust or understanding can arise within the group. A possible way to achieve a shared agenda is for group members to perform collaborative research and consequently generating shared knowledge (Barak et al., 2010). In this process, attention is necessary for achieving a balance between individual accountability and positive interdependence linked to group goals (Hornby, 2009). Individual accountability refers to the extent to which the performance of each individual group member is assessed as well as the results given back to the group and the individual. In the case of positive interdependence, group members perceive that they can only reach their learning goals if the other group members also reach their goals.

To summarise, key indicators of domain and value creation in teacher groups are:

- 'Sharing or broadening/deepening knowledge and skills', reflecting the extent to which the group develops collective knowledge and skills through dialogue;

- 'Individual or collective value creation', which describes the level to which the group develops shared value such as group ownership, mutual inspiration, or positive interdependence.

\subsection{Dimension 3: Collective Identity}


When group members work interdependently with a shared purpose and responsibility for collective success it can result in a shared identity (Knapp, 2010). Such working conditions promote teachers' collective reflection and open dialogue and enhance group learning (Ohlsson, 2013). Participants of a group that already have a shared history (Akkerman et al., 2008) are more likely to recognize a shared vision consisting of joined needs and interests (Garcia-Moralez, Lopez-Martin, \& Llamas-Sanchez, 2005).

Groups that aim at stimulating a shared identity are advised to discuss the questions of who they are and how they can be important for each other. For instance through story telling and scanning (Meirink et al., 2010). In this way, a feeling of belonging to the group can be created (De Laat, 2012a). For teacher groups to function and exist, it is important that the participants feel responsible for their group activity by integrating their perspectives and by ensuring an interwoven-ness of individual tasks (Doppenberg et al., 2012) through 'aid and assistance' that allows colleagues to observe each others' teaching practices, 'sharing' or exchanging instructional materials, methods, ideas and opinions, and 'joint work' in which teachers sense a collective responsibility for their teaching (Meirink et al., 2010).

The attention to relations or interactions between people is an important aspect of a social network approach to learning (Haythornthwaite \& De Laat, 2012). The presence of cohesive, interpersonal relationships or ties in the group is considered an important condition for knowledge sharing (Agterberg et al., 2009). In the concept of communities of practice (Wenger, 1998), people demonstrate long-lasting social relationships related to their practice and domain. These strong ties can be characterized as proximal, frequent, reciprocal and multi-redundant (Carmichael, Fox, McCormick, Procter, \& Honour, 2006) which makes participants experience a strong inward focus that enhances deeper knowledge development.

However, strong ties appear less productive for the innovative and outward focus of the group (Hanraets et al., 2011). An external view of the group requires weak ties that can be analysed as distant, infrequent, and not reciprocal. This emphasizes the importance for teacher groups to value both internal and external connections for professional development (Carmichael et al., 2006).

Investigating who interacts with whom to discover the existence of weak or strong ties contributes to an understanding of the sense of general contact among learners. Agterberg et al. (2009) use the term 'structural embedded-ness' that refers to the structure of connections among people. Questions concerning the content, direction, and strength of these interactions can be asked to gain a more intense analysis of the groups' interaction (Haythorntwaite \& De Laat, 2012). Some people may be densely tied, i.e., engaged in many different kinds of 
relations, interacting frequently and/or in relations that are of high personal significance. Others may be weakly tied, i.e., engaging occasionally with partial commitment to the activities of the network.

In addition to 'structural embedded-ness', Agterberg et al. (2009) use 'organizational embedded-ness' to refer to the extent to which group knowledge is integrated in and relevant to the organization of which the groups are part. The participants of a group not only work on their tasks, but also share knowledge within their group in the form of new rules, routines, strategies, best practices, etc. This attitude enables the group to develop a more long-term perspective with a focus on continuous learning.

To establish a learning situation where the participants can flourish in a self-regulated manner from a continuous learning mode, it is of importance to fulfil diverse positions within groups (Haythornthwaite \& De Laat, 2012). Besides more familiar positions such as the 'network star' (people who give information or other resources to many others), 'gatekeepers' (people who bring information from outside the network into the network) and the 'technological guru' (people who are everyone's resource for questions about the use of technologies), recent work is beginning to reveal new learning positions in online learning environments (Haythornthwaite \& De Laat, 2012), such as 'e-facilitators' (people who help in online learning environments to shape the argument, provide summaries and influence the direction of the discussion), 'braiders' (people who take the online community discussions and reinterpret these in different styles and for different audiences), and 'accomplished fellows' (people who set up working parties to explore a subject in more depth). These new learning positions are examples of how group members collaborate as knowledge workers, which stands in contrast to groups where members are focused on execution of given tasks.

The dimension collective identity can be characterized by:

- 'Shared or unshared identity', which is related to group history and social and cultural background;

- 'Strong or weak ties', which reflects the sense and intensity of general contact among group members;

- The extent to which group members perceive each other as 'task executors or knowledge workers'.

\subsection{Dimension 4: Organization}


Self-regulated learning (SRL) is defined as a goal-oriented process, proceeding from a forethought phase through self-monitoring and self-control to self-reflection (Pintrich, 2004). Although SRL is generally considered as a personal characteristic, many researchers have shown the benefits of group activities for enhancing SRL (Beishuizen, 2008). Since the effects of learning in teacher groups vary depending on self-regulation by the participants (Laferrière, Lamon, \& Chan, 2006), group members are required to possess sufficient metacognitive skills or knowledge.

The transition from externally directed to self-organized learning in teacher groups should be a gradual process ('scaffolding') guided by facilitators, to enhance social learning in teacher groups (Vrieling et al., 2010). These facilitators have five roles that are important especially during the start-up phase of the group. The facilitators roles are: information source, inspirer, guide, public relations manager and investigator (Hanraets et al., 2011). Research shows that facilitators are only successful when two fundamental questions are elaborated, representing respectively the domain and the identity of the group: (1) 'How are we relevant to each other?' and (2) 'Who are we and where we are going?' (Akkerman et al., 2008). When the group facilitator discusses these questions at an earlier stage with group members, a meaningful, shared context within the group develops with the promise of a development towards an active, self-regulating group. This team reflexivity (Knapp, 2010) can be viewed as a combination of collective metacognition and team reflection.

De Laat and Coenders (2011) distinguish local and global activities as part of social learning. Teacher groups develop specific, contextual knowledge, as well as more general knowledge. Although teachers often act local, it is fruitful for teacher groups to share their knowledge and expertise. In this way, small and local teacher groups can be cultivated towards more global oriented groups. Successful groups with a global orientation draw people together from disparate contexts around shared challenges, yet also sustain the ability to stay close to the local needs of their members.

The hierarchical structures within formal groups can hinder spontaneous learning in informal learning settings (De Laat, 2012a). After all, in the literature we found arguments supporting the importance for all members to be actively involved and feel responsible for a proper outcome of the group. In such settings, distributed leadership appears an attractive concept to enhance professional development of teacher groups. Based on the expertise of the participants, learning environments can be created in which all members can contribute to problems and challenges concerning school improvement. 
Interactions are essential for enhancing group-learning processes. However obvious this seems, the importance lies in group-members to find a balance between individual goals and accountability, and group goals (Chamberlin-Quinsilk, 2010). Dialogues between groupmembers establishing and maintaining positive interdependence are often mentioned as important aspects of social interaction (Barak et al., 2010; Chamberlin-Quinsilk, 2010). Interactions take place between learners, between learners and teachers, and between learners and content. Facilitated by technological developments, such as virtual learning environments or social media, interactions between learner and computer applications, and learner and community have gained importance in recent years (Leh et al., 2005).

To summarize, teacher group organization can be characterized by:

- The extent to which the group shows 'externally directed or self-organized learning';

- The focus on 'local or global activities';

- The presence of 'hierarchic or equal relationships';

- The extent to which the group shows a shared interactional repertoire, reflected in 'shared or non-shared interactional norms'.

\subsection{Summary of the Findings}

The features of social learning as discussed above in 4 dimensions and 11 subsequent indicators, are a guide to assess and reflect upon the configuration of a group, rather than to make a value judgment about teacher groups. The dimensions serve as a lens or framework to look at the current social configuration of a teacher group. It helps to understand the group's activities from a learning perspective containing aspects of teams, communities and networks. In this way, the behaviour of the group in relation to their learning goals is assessed. Based on this analysis, the group can reflect on how their social configuration fits with their purpose and learning goals.

The approach taken in this study was based on the notion that teams, networks and communities are often strongly driven by purely theoretical ideas. In practice, however, groups develop mixed forms of social learning, emphasising different aspects at different times (Wenger et al., 2011). For instance, a team is never purely a team because it integrates aspects of community and networking during its existence.

The 11 indicators were translated into bipolar questions in order to create a future assessment tool that enables a characterization of the group for each indicator. Overall, such 
an instrument can support social learning groups in characterising their potential social value as an indicator for professional development.

Table 1. Social learning dimensions and their indicators

\section{Practice}

1a. To what extent does the group exhibit integrated or non-integrated group activities in daily work?

1b. To what extent does the group exhibit temporarily or permanent social activities?

2. Domain and value creation

2a. To what extent does the group focus on sharing or broadening/deepening knowledge and skills?

2b. To what extent does the group experience value creation, individually or collectively?

3. Collective identity:

3a. To what extent do participants exhibit a shared or unshared identity?

3b. To what extent does the group exhibit weak or strong ties?

3c. To what extent do the participants view one another as task executors or knowledge workers?

4. Organization:

4a. To what extent does the group operate externally directed or self-organized?

4b. To what extent does the group exhibit 'local' or 'global' activities?

4c. To what extent does the group exhibit hierarchic of equal relationships?

4d. To what extent does the group exhibit shared or non-shared interactional norms?

\section{Discussion}

This paper contributes to a new theoretical framework for analysing and describing different forms of social learning within teacher groups. Based on a conceptual review of the literature on team learning, community learning and network learning, a framework with 4 dimensions 
and 11 indicators of social learning was developed. This framework can be applied to bring the current social configuration of a given group into focus and in doing so support teachers' professional development.

Our journey started from the notion that research literature often emphasizes the theoretical constructs of teams, communities and networks, which are empirically sought after in their 'pure' existence. This leads to research and models to decide if, for example, a 'community' is truly a 'community', applied to make claims about the way they learn. However, in line with Wenger et al. (2011), we argue that everyday practice shows mixed forms of these types of learning groups. We also recognize the development into a networked society, which makes it valuable to think of learning groups as participating in open practices (De Laat, Schreurs, \& Nijland, 2014; Pugh \& Prusak, 2013). In perspective of our framework this development is expected to influence the identity of the group and subsequently the dimensions shared domain and interactional repertoire as distinguished by Wenger.

By means of a literature review, we examined whether group typology appears to be trivial to its functioning. Because teacher groups address different goals, they differ on the four dimensions of social learning. Through assessing the group on the four overarching dimensions and their indicators, teacher groups become more aware of the potential value of their group for future development.

Despite the systematic inquiry method of the literature search, the validity of conclusions cannot be taken for granted. The framework of dimensions and indicators is based solely on a literature review which implies some caution when drawing conclusions. Furthermore it is important to recognize that the reviewed literature is situated in a specific social and cultural context, which may vary across different learning settings (see also Roth \& Lee, 2007).

Although the framework as discussed in this review might prove effective for teachers' reflection on which configuration of social learning best fits their collaborative goals, recommendations must be explicit about the behaviour that is expected from teachers. Therefore, in future research, we will continue to explore the operationalization of the framework towards a diagnostic instrument for teacher groups.

First steps have been made in applying and validating the framework. In the context of a European study on open educational resources (POERUP), the framework served as guidance for semi-structured interviews (Schreurs, Van den Beemt, Prinsen, De Laat, Withaus, \& Conole, submitted). Furthermore, the framework has been applied in the context of teacher group settings. In these groups, teachers interact with colleagues, student teachers, 
information and resources as they tackle real-life challenges. Based on a descrition or snapshot of the current social structure in dimensions and indicators, teacher groups can assess new directions for professional development. Our findings suggest that it is beneficial for groups to discuss the following questions: given this group, how are the dimensions and including indicators intertwined and integrated, how do they contribute to the cohesion and functioning of the group, and which one tends to dominate? What learning opportunities do they offer and what value do they produce? The importance of this approach is to acknowledge the unique social setting, dynamics and desires of each group as it is situated in their practice. Based on the configuration of the group, professional development applying these dimensions can be encouraged.

Grounded in the social learning framework, future research can aim at the translation of the dimensions and indicators into an instrument that also provides guidelines to support social learning processes in teacher groups. Both the instrument and the accompanying guidelines can support social learning activities of teachers and their professional development.

\section{References}

Admiraal, W., Lockhorst, D., \& Van der Pol, J. (2012). An expert study on a descriptive model of teacher communities. Learning Environments Research, 15(3), 345-361.

Agterberg, M., Van den Hooff, B., Huysman, M, \& Soekijad, M. (2009). Keeping the wheels turning: The dynamics of managing networks of practice. Journal of Management Studies, 47(1), 85-108.

Akkerman, S., Petter, C, De Laat, M. (2008). Organising communities-of-practice: Facilitating emergence. Journal of Workplace Learning, 20(6), 383-399.

Barak, J., Gidron, A., \& Turniansky, B. (2010). 'Without stones there is no arch': A study of professional development of teacher educators as a team. Professional Development in Education, 36(1-2), 275-287

Beishuizen, J. (2008). Does a community of learners foster self-regulated learning? Technology, Pedagogy and Education, 17(3), 183-193.

Carmichael, P., Fox, A., McCormick, R., Procter, R., \& Honour, L. (2006). Teachers' networks in and out of school. Research Papers in Education, 21(2), 217-236.

Chamberlin-Quinsilk, C. (2010). Cooperative learning as method and model in second language teacher education. Intercultural Education, 21(3), 243-255. 
Chappuis, S., Chappuis, S., \& Stiggins, R. (2009). Supporting teacher learning teams. Educational Leadership, 66(5), 56-60.

Dechant, K., Marsick, V. J., \& Kasl, E. (1993). Towards a model of team learning. Studies in Continuing Education, 15(1), 1-14.

De Laat, M. (2012a). Netwerkleren. In M. Ruijters, \& P.R.J. Simons (Eds), Canon van het leren. Deventer: Kluwer.

De Laat, M. (2012b). Enabling professional development networks: How connected are you? Heerlen: Open Universiteit of the Netherlands.

De Laat, M., \& Coenders M. (2011). Communities of Practice en netwerkleren. In J. Kessels, \& R. Poell (Eds.), Handboek human resource development: Organiseren van het leren (pp. 417-428). Houten: Bohn Stafleu van Logum.

De Laat, M., Schreurs, B., \& Nijland, F. (2014). Communities of Practice: Balancing openness, networking and value creation. In R.F. Poell, T.S. Rocco, \& G.L. Roth (Eds.), The Routledge companion to human resource development. London: Routledge.

Doornbos, A., \& De Laat, M. (2012). De waarde van CoPs in het Groene Onderwijs [The value of CoPs in green education]: Onderzoeksrapport ter ondersteuning van de doorstart van CoPs met de nadruk op verbindend leren en zichtbaar ontwikkelen. Heerlen: Scientific Centre for Teacher Research (LOOK).

Doppenberg, J., Bakx, A., \& Den Brok, P. (2012). Collaborative teacher learning in different primary school settings. Teachers and Teaching: Theory and Practice, 18(5), 547-566.

Garcia-Moralez, V., Lopez-Martin, F., \& Llamas-Sanchez, R. (2005). Strategic factors and barriers for promoting educational organizational learning. Teaching and Teacher Education, 22, 478-502.

Goodman, P., \& Dabbish, L. (2011). Methodological issues in measuring group learning. Small Group Research, 42(4), 379-404.

Guskey, T.R. (2002). Professional development and teacher change. Teachers and Teaching: Theory and Practice, 8(3), 381-391.

Hanraets, I., Hulsebosch, J., \& De Laat, M. (2011). Experiences of pioneers facilitating teacher networks for professional development. Educational Media International, 48(2), 85-99.

Haythornthwaite, C., \& De Laat, M. (2012). Social network informed design for learning with educational technology. In A.D. Olofsson, \& J.O. Lindberg (Eds.), Informed design of 
educational technologies in higher education: Enhanced learning and teaching (pp. 352-394). Amazon.

Hornby, G. (2009). The effectiveness of cooperative learning with trainee teachers. Journal of Education for Teaching: International Research and Pedagogy, 32(5), 161-168.

Knapp, R. (2010). Collective (team) learning process models: A conceptual review. Human Resource Development Review, 9(3), 285-299.

Laferrière, T., Lamon, M., \& Chan, C.K.K. (2006). Emerging e-trends and models in teacher education and professional development. Teaching Education, 17(1), 75-90.

Leh, A., Kouba, B., \& Davis, D. (2005). Twenty-first century learning: communities, interaction and ubiquitous computing. Educational Media International, 42 (3), 237250.

Lieberman, A. (2000). Networks as learning communities: Shaping the future of teacher development. Journal of Teacher Education, 51(3), 221-227.

Lieberman, A., \& Pointer Mace, D. (2010). Making practice public: Teacher learning in the 21st century. Journal of Teacher Education, 61(1-2), 77-88.

Lieberman, A., \& Wood, D.R. (2003). Inside the National Writing Project: Connecting network learning and classroom teaching. New York: Teachers College Press.

Little, J.W. (2003). Inside teacher community: Representations of classroom practice. Teachers College Record, 105(6), 913-945.

Meirink, J., Imants, J., Meijer, P.C., \& Verloop, N. (2010). Teacher learning and collaboration in innovative teams. Cambridge Journal of Education, 40(2), 161-181.

Nash, P., \& Shaffer, D. W. (2011). Mentor modelling: The internalization of modelled professional thinking in an epistemic game. Journal of Computers Assisted Learning, 27(2), 173-189.

Ohlsson, J. (2013). Team learning: Collective reflection processes in teacher teams. Journal of Workplace Learning, 25(5), 296-309.

Pintrich, P.R. (2004). A conceptual framework for assessing motivation and self-regulated learning in college students. Educational Psychology Review, 16(4), 385-407.

Pugh, K., \& Prusak, L. (2013). Designing effective knowledge networks. MIT Sloan Management Review, Fall 2013.

Roth, W.M., \& Lee, Y.J. (2007). Vygotsky's neglected legacy: Cultural-historical activity theory. Review of Educational Research, 77(2), 186-232. 
Salas, E., Dickinson, T. L., Converse, S. A., \& Tannenbaum, S. I. (1992). Toward an understanding of team performance and training. In R.W. Swezey, \& E. Salas (Eds.), Teams: Their training and performance (pp. 3-29). Norwood, NJ: Ablex.

Savelsbergh, C., Van der Heijden, B., \& Poell, R. (2009). The development and empirical validation of a multidimensional measurement instrument for team learning behaviors. Small Group Research, 40(5), 578-607.

Schreurs, B., Van den Beemt, A., Prinsen, F., De Laat, M., Withaus, G., \& Conole, G. (submitted). Investigating the social configuration of a community to understand how networked learning activities take place: The POERUP case-study.

Strijbos, J. W., Martens, R., Jochems, W., \& Broers, N. (2004). The effect of functional roles on group efficiency: Using multilevel modeling and content analysis to investigate computer-supported collaboration in small groups. Small Group Research, 35(2), $195-$ 229.

Van den Beemt, A., Ketelaar, E., \& Diepstraten, I. (2014). Reciprocity in knowledge networks. Paper accepted for the 2014 Networked Learning Conference, Edinburgh, UK.

Van den Bossche, P., Gijselaers, W., Segers, M., \& Kirschner, P. (2006). Social and cognitive factors driving teamwork in collaborative learning environments: Team learning beliefs and behaviors. Small Group Research, 37(5), 490-521.

Van Emmerik, H., Jawahar, I., Schreurs, B., \& De Cuyper, N. (2011). Social capital, team efficacy and team potency: The mediating role of team learning behaviors. Career Development International, 16(1), 82-99.

Vrieling, E.M., Bastiaens, Th.J., \& Stijnen, P.J.J. (2010). Process-oriented design principles for promoting self-regulated learning in primary teacher education. International Journal of Educational Research, 49(4-5), 141-150.

Wenger, E. (1998). Communities of practice: Learning, meaning and identity. Cambridge: University Press.

Wenger, E., Trayner, B., \& De Laat, M. (2011). Telling stories about the value of communities and networks: A toolkit. Heerlen: Open University of the Netherlands. 